\title{
UPAYA PENGELOLAAN LINGKUNGAN PENGGALIAN DAN PENGAMBILAN MATERIAL PASIR DAN BATU DALAM RANGKA PEMELIHARAAN SUNGAI GENDOL KECAMATAN CANGKRINGAN KABUPATEN SLEMAN
}

\author{
Dwi Herniti \\ Yogyakarta Institute of Technology, J1. Janti Km. 04, Kabupaten Bantul 55198 \\ email: dwi.herniti@gmail.com
}

\begin{abstract}
ABSTRAK
Aktivitas penggalian dan pengambilan material pasir dan batu di Desa Kepuharjo dikelola oleh pemegang Wilayah Izin Usaha Pertambangan Izin Usaha Pertambangan Eksplorasi Mineral Bukan Logam dan Batuan Komoditas Pasir dan Batu atas nama Muhammad Affan, Izin pertambangan tersebut diterbitnya oleh Kantor Pelayanan Perizinan Terpadu Satu Pintu Daerah Istimewa Yogyakarta Tahun 2016. Aktivitas penggalian dan pengambilan material pasir dan batu dilakukan sebagai upaya pemeliharaan Sungai Gendol. Meskipun demikian, aktivitas penggalian dan pengambilan material pasir dan batu diperkirakan menimbulkan dampak lingkungan terhadap lingkungan. Dampak yang diperkirakan timbul berupa terjadinya longsor, penurunan kualitas udara, peningkatan kebisingan, kecelakaan kerja, kerusakan jalan serta gangguan kelancaran lalu lintas. Upaya pengelolaan lingkungan diperlukan sebagai upaya meminimalisir dampak lingkungan serta pemakaian sumber daya alam yang bijaksana dan berkelanjutan. Upaya pengelolaan lingkungan pada aktivitas penggalian dan pengambilan material pasir dan batu di Desa Kepuharjo meliputi pembuatan penguat tebing sungai, penggalian dan pengambilan material pasir dan batu sesuai prosedur yang berlaku, serta aktivitas pengangkutan dan bongkar muat material sesuai prosedur yang berlaku.
\end{abstract}

Kata kunci: penggalian pasir, sungai gendol

\section{ENVIRONMENTAL MANAGEMENT EFFORTS OF EXCAVATION AND TAKING OF SAND AND STONE MATERIALS IN MAINTENANCE OF THE GENDOL RIVER, DUSUN KALIADEM, KECAMATAN CANGKRINGAN, SLEMAN DISTRICT}

\begin{abstract}
The excavation and extraction of sand and stone material in Kepuharjo Village are managed by the holder of the Mining Business Permit for Non-Metal Mineral and Rock Commodity Exploration Mining Business Permits on behalf of Muhammad Affan, the mining permit was issued by the One Stop Integrated Licensing Service Office of Yogyakarta Special Region. 2016. Activities of excavating and extracting sand and stone materials are carried out as an effort to maintain the Gendol River. However, it is estimated that the excavation and extraction of sand and rock materials will have an environmental impact on the environment. The impacts that are expected to occur are landslides, decreased air quality, increased noise, work accidents, road damage and traffic disruption. Environmental management efforts are needed as an effort to minimize environmental impacts and the wise and sustainable use of natural resources. Environmental management efforts in the excavation and extraction of sand and stone materials in Kepuharjo Village include the manufacture of river cliff reinforcements, excavation and extraction of sand and stone material according to applicable procedures, as well as material transportation and loading and unloading activities according to applicable procedures.
\end{abstract}

Keywords: excavation of sand, sungai gendol

\section{PENDAHULUAN}

Desa Kepuharjo, Kecamatan Cangkringan, Kabupaten Sleman, Daerah Istimewa Yogyakarta merupakan daerah potensi tambang bahan galian pasir dan batu. Saat ini pengelola tambang bahan galian pasir dan batu dilakukan oleh pemegang Wilayah Izin Usaha Pertambangan (WIUP) yang diterbitkan oleh Kantor Pelayanan Perizinan Terpadu Satu Pintu DIY Nomor 545/5422/KP2TSP/2016 tentang Pemberian Izin Wilayah Usaha Pertambangan Bukan Logam dan Bantuan Komoditas Pasir dan Bantu kepada Muhammad Affan dan dan Izin Usaha Pertambangan (IUP) Eksplorasi berdasarkan Keputusan Kepala Kantor Pelayanan Perizinan Terpadu Satu Pintu Daerah Istimewa Yogyakarta Nomor 545/5738/KP2TSP/2016 tentang Persetujuan Izin Usaha Pertambangan Eksplorasi Mineral Bukan Logam dan Batuan Komoditas Pasir dan Batu.

Kegiatan penambangan dilakukan dengan mengambil material sungai yakni pasir dan batu dengan tujuan untuk mengembalikan fungsi sungai sesuai dengan peruntukannya, sehingga kegiatan ini merupakan upaya dalam rangka pemeliharaan sungai. Meskipun demikian, kegiatan penambangan pasir 
dan batu dimungkinkan menimbulkan dampak terhadap lingkungan diantaranya pada aktivitas pengerukan pasir dengan alat berat, pengisian hasil galian ke truk pengangkut, proses pengangkutan, aktivitas kantor lapangan dan pos jaga. Jika terjadi penambangan yang berlebihan dan tidak diperhitungkan dengan baik, akan menyebabkan perubahan yang signifikan pada tebing-tebing lereng maupun tebing sungai Hal itu berpotensi menimbulkan bencana tanah longsor jika dilakukan secara masif.(Herniti, 2016)

Dampak yang ditimbulkan meliputi pencemaran udara, peningkatan kebisingan, timbulnya getaran, kecelakaan kerja, terjadinya longsor, kerusakan jalan, gangguan kelancaran lalu lintas, timbulan sampah dan timbulan limbah cair domestik.

Tujuan dari penelitian ini adalah untuk mengkaji dampak lingkungan dari kegiatan penambangan pasir dan batu di Dusun Kaliadem Desa Kepuharjo Kecamatan Cangkringan Kabupaten Sleman dan merumuskan upaya pengelolaan dari dampak lingkungan yang kemungkinan timbul.

\section{METODE PENELITIAN}

Metode yang digunakan dalam penelitian ini adalah observasi langsung pada lokasi kegiatan kemudian dilakukan kajian dampak lingkungan dari seluruh aktivitas di lokasi penambangan pasir dan batu serta di sekitar lokasi kegiatan, kemudian dari dampak lingkungan yang diperkirakan timbul dilakukan perumusan upaya pengelolaan lingkungan berikut dengan lokasi dan periode pengelolaan lingkungan. Perumusan upaya pengelolaan lingkungan dilakukan dengan melakukan studi pustaka dan penelitian terkait lainnya.

\section{HASIL DAN PEMBAHASAN}

Jenis izin yang dimiliki pada kegiatan penggalian dan pengambilan material pasir dan batu Desa Kepuharjo dengan milik Muhammad Affan diuraikan pada Tabel 1 berikut:

Tabel 1. Jenis Izin yang Dimiliki kegiatan penggalian dan pengambilan material pasir dan batu Desa Kepuharjo

\begin{tabular}{lllll}
\hline No. & Jenis Izin & Nomor & Instansi & $\begin{array}{l}\text { Tanggal } \\
\text { terbit }\end{array}$ \\
\hline 1 & Persetujun Izin WIUP & $545 / 5422 /$ KP2TSP/2016 & $\begin{array}{l}\text { Kantor Pelayanan } \\
\text { Perijinan Terpadu } \\
\text { Satu Pintu DIY }\end{array}$ & $\begin{array}{l}\text { 7 Desember } \\
2016\end{array}$ \\
\hline 2 & Persetujuan Izin Eksplorasi & $545 / 5738 /$ KP2TSP/2016 & $\begin{array}{l}\text { Kantor Pelayanan } \\
\text { Perijinan Terpadu } \\
\text { Satu Pintu DIY }\end{array}$ & $\begin{array}{l}22 \\
\text { Desember } \\
2016\end{array}$ \\
\hline 3 & $\begin{array}{l}\text { Persetujuan RKAB } \\
\text { Eksplorasi }\end{array}$ & $540 / 04687$ & $\begin{array}{l}\text { Dinas PUPESDM } \\
\text { DIY }\end{array}$ & $\begin{array}{l}17 \text { Maret } \\
2017\end{array}$ \\
\hline 4 & $\begin{array}{l}\text { Persetujuan Laporan } \\
\text { Eksplorasi }\end{array}$ & $540 / 08059$ & Dinas PUPESDM & D Mei 2017 \\
\hline 5 & $\begin{array}{l}\text { Persetujuan Laporan Studi } \\
\text { Kelayakan }\end{array}$ & $540 / 13943$ & $\begin{array}{l}\text { Dinas PUPESDM } \\
\text { DIY }\end{array}$ & $\begin{array}{l}\text { 1 Agustus } \\
\text { 2017 }\end{array}$ \\
\hline 6 & $\begin{array}{l}\text { Persetujuan Laporan } \\
\text { Rencana Reklamasi dan } \\
\text { Rencana Pasca Tambang }\end{array}$ & $540 / 13937$ & Dinas PUPESDM & 31 Juli \\
\hline \multirow{2}{*}{7} & $\begin{array}{l}\text { Persetujuan Rencana } \\
\text { Pengembangan dan } \\
\text { Pemberdayaan Masyarakat } \\
\text { Sekitar }\end{array}$ & $540 / 13942$ & DIY & 2017 \\
\hline 8 & Rekomendasi Teknis & HK-0601-Aq/814 & BBWSSO & $\begin{array}{l}\text { 21 Juli } \\
\text { 2017 }\end{array}$ \\
\hline
\end{tabular}

Sumber : Data Sekunder, 2020

Wilayah Penggalian dan Pengambilan Pasir dan Batu batu Desa Kepuharjo dengan milik Muhammad Affan diuraikan pada Tabel 2 sebagai berikut:

Tabel 2. Wilayah Penggalian dan Pengambilan Pasir dan Batu batu Desa Kepuharjo 


\begin{tabular}{|c|c|c|c|c|}
\hline No & Item & & Nominal & Satuan \\
\hline 1 & Luasan & & 33.100 & $\mathrm{~m}^{2}$ \\
\hline 2 & Volume & & 165.500 & $\mathrm{~m}^{3}$ \\
\hline 3 & Lebar rata-rata & & 85 & $\mathrm{M}$ \\
\hline 4 & Panjang & & 380 & $\mathrm{M}$ \\
\hline 5 & Kedalaman rata-rata & & 5 & $\mathrm{~m}^{3}$ \\
\hline 6 & Kemiringan dasar & & 8 & $\%$ \\
\hline 7 & Kemiringan lereng/tebing & & 30 & $\%$ \\
\hline 8 & Produksi harian & & 460 & $\mathrm{~m}^{3}$ \\
\hline 9 & Jumlah tenaga kerja & & 16 & Orang \\
\hline \multirow[t]{5}{*}{10} & Batas & & & \\
\hline & & Utara & \multicolumn{2}{|c|}{ Alur Sungai Gendol } \\
\hline & & Selatan & \multicolumn{2}{|c|}{ Alur Sungai Gendol } \\
\hline & & Barat & \multirow{2}{*}{\multicolumn{2}{|c|}{ Alur Sungai Gendol (Desa Kepuharjo) }} \\
\hline & & Timur & Alur Sungai Gendol (Desa Glagaharjo) & \\
\hline
\end{tabular}

Sumber : Data Sekunder, 2020

Jam kerja penggalian pasir dan batu di lokasi kegiatan dilakukan mulai pukul 08.00 WIB hingga pukul 17.00 WIB (8 jam) dengan waktu istirahat 1 jam. Jenis peralatan yang digunakan dalam penggalian meliputi alat berat berupa excavator dan dump truck, sedangkan non alat berat meliputi cangkul dan sekop dan alat pendukung berupa ayakan. Sedangkan bangunan penunjang yang dibangun meliputi kantor lapangan, pos jaga, mushola, toilet dan tangki solar.

Dari hasil observasi di lokasi kegiatan. dampak yang ditimbulkan dari aktivitas penambangan pasir dan batu Desa Kepuharjo terjadi pada kegiatan pengangkutan hasil penggalian, aktivitas kantor lapangan dan pos jaga, serta penggunaan mushola dan toilet. Uraian kegiatan, dampak yang ditimbulkan serta upaya pengelolaan lingkungan diuraikan sebagai berikut;

1. Kegiatan Penggalian dan Pengambilan

Dampak lingkungan serta upaya pengelolaannya meliputi;

1) Peningkatan partikel debu

a. Upaya Pengelolaan Lingkungan

- Penutupan pasir di atas truk pengangkut dengan terpal yang memenuhi syarat teknis, sehingga tidak menimbulkan debu yang bisa mencemari lingkungan di sekitar jalan akses keluar truk,

- Melakukan penyiraman di lokasi yang sangat potensial menimbulkan debu,

- Melakukan perbaikan, penyiraman jalan yang dilalui armada angkut sehingga bisa mengurangi timbulnya debu,

- Mengatur penuangan pasir ke dalam truk (sedikit pelan-pelan) sehingga bisa mengurangi timbunya debu

b. Lokasi Pengelolaan Lingkungan

Jalur pengangkutan Penggalian di Dusun Kaliadem Desa Kepuharjo Kec Cangkringan

c. Periode Pengelolaan Lingkungan

Selama masa penggalian dan pengambilan

2) Timbulnya kebisingan

a. Upaya Pengelolaan Lingkungan

- Kegiatan pengangkutan peralatan dan material pada tahap penggalian dilakukan pada jam kerja, sehingga tidak mengganggu jam belajar masyarakat dan ketenangan di malam hari untuk beristirahat

- Kegiatan pengangkutan dibatasi, yaitu dilakukan pada jam 08.00 - 17.00

- Perawatan mesin alat berat secara berkala

- Mengikuti SOP yang ada sesuai prosedur

b. Lokasi Pengelolaan Lingkungan

Di pemukiman dan di lokasi penggalian

c. Periode Pengelolaan Lingkungan

Selama masa penggalian dan pengambilan

3) Timbulnya getaran

a. Upaya Pengelolaan Lingkungan 
Armada angkut menggunakan truk yang tidak terlalu besar se-hingga tidak menimbulkan geta-ran yang cukup kuat

b. Lokasi Pengelolaan Lingkungan

Di lokasi penggalian dan sekitarnya serta jalan yang dilalui armada truk

c. Periode Pengelolaan Lingkungan

Selama kegiatan penggalian dan pengambilan

4) Kecelakaan Kerja

a. Upaya Pengelolaan Lingkungan

- Berhati-hati dalam pengoperasian alat

- Mererapkan Keamanan dan Keselamatan Kerja (K3).

- Menggunakan pengaman dan keselamatan kerja seperti wear peak.

b. Lokasi Pengelolaan Lingkungan

Di lokasi penggalian dan sekitarnya serta jalan yang dilalui armada truk

c. Periode Pengelolaan Lingkungan

Selama kegiatan penggalian dan pengambilan

5) Terjadinya Longsor

a. Upaya Pengelolaan Lingkungan

- Berhati-hati dalam melakukan penggalian dan pemuatan serta mematuhi aturan metode kerja

- Membuat penguat tebing sungai

b. Lokasi Pengelolaan Lingkungan

Di lokasi penggalian dan sekitarnya

c. Periode Pengelolaan Lingkungan

Selama kegiatan penggalian

6) Timbulan Sampah

a. Upaya Pengelolaan Lingkungan

- Penyediaan tempat sampah dan TPS

- Koordnasi dengan DLH/PU Kabupaten Sleman dalam pengangkutan sampah dari TPS ke TPA

b. Lokasi Pengelolaan Lingkungan

Di kantor lapangan dan pos penjagaan

c. Periode Pengelolaan Lingkungan

Selama masa penggalian dan pengambilan pasir dan batu

7) Timbulan Limbah Cair Domestik

a. Upaya Pengelolaan Lingkungan

- Penyediaan MCK dengan dilengkapi septiktank

- Penyedotan tangki septik secara berkala

- Memasang papan peringatan unuk menerapkan pola hidup bersih dan sehat (PHBS)

b. Lokasi Pengelolaan Lingkungan

Di lokasi MCK

c. Periode Pengelolaan Lingkungan

Selama masa penggalian dan pengambilan pasir dan batu

2. Kegiatan Pengangkutan Hasil Penggalian dan Pengambilan

1) Kerusakan Jalan

a. Upaya Pengelolaan Lingkungan

- Mengatur beban kendaraan pengangkut (hanya boleh menggunakan truk dengan kapasitas maksimal $4 \mathrm{~m}^{3}$ ).

- Memperbaiki jalan yang rusak bekerjasama dengan instansi yang berwenang

b. Lokasi Pengelolaan Lingkungan

Di lokasi penggalian dan sekitarnya serta jalan yang dilalui armada truk

c. Periode Pengelolaan Lingkungan

Selama masa penggalian dan pengambilan pasir dan batu

2) Gangguan Kelancaran Lalu Lintas

a. Upaya Pengelolaan Lingkungan

- Pemasangan rambu di jalan masuk lokasi Penggalian Penggalian pasir dan batu yang rawan kemacetan dan rawan terjadi kecelakaan, 
- Menempatkan petugas pengatur lalu lintas di jalan masuk area penggalian pasir dan batu

b. Lokasi Pengelolaan Lingkungan

Di lokasi penggalian dan sekitarnya serta jalan yang dilalui armada truk

c. Periode Pengelolaan Lingkungan

Selama masa penggalian dan pengambilan pasir dan batu

3) Peningkatan Debu

a. Upaya Pengelolaan Lingkungan

- Melakukan penyiraman jalan

- Menggunakan penutup terpal pada angkutan pasir

b. Lokasi Pengelolaan Lingkungan

Di lokasi penggalian dan sekitarnya serta jalan yang dilalui armada truk

c. Periode Pengelolaan Lingkungan

Selama masa penggalian dan pengambilan pasir dan batu

4) Peningkatan Kebisingan

a. Upaya Pengelolaan Lingkungan

- Kegiatan pengangkutan peralatan dan material pada tahap penggalian dilakukan pada jam kerja, sehingga tidak mengganggu jam belajar masyarakat dan ketenangan di malam hari untuk beristirahat

- Kegiatan pengangkutan dibatasi, yaitu dilakukan pada jam 08.00 - 17.00

- Perawatan mesin alat berat secara berkala

- Mengikuti SOP yang ada sesuai prosedur

b. Lokasi Pengelolaan Lingkungan

Di lokasi penggalian dan sekitarnya serta jalan yang dilalui armada truk

c. Periode Pengelolaan Lingkungan

Selama masa penggalian dan pengambilan pasir dan batu

5) Peningkatan Getaran

a. Upaya Pengelolaan Lingkungan

Armada angkut menggunakan truk yang tidak terlalu besar se-hingga tidak menimbulkan geta-ran yang cukup kuat

b. Lokasi Pengelolaan Lingkungan

Di lokasi penggalian dan sekitarnya serta jalan yang dilalui armada truk

c. Periode Pengelolaan Lingkungan

Selama masa penggalian dan pengambilan pasir dan batu

\section{KESIMPULAN}

Kegiatan penambangan pasir dan batu di Desa Kepuharjo dengan nama pengelola Muhammad Affan telah memiliki izin eksplorasi untuk dilakukan penggalian dan pengambilan. Meskipun demikian, dampak lingkungan diperkirakan timbul dari adanya kegiatan penggalian dan pengambilan serta pengangkutan material. Dampak yang ditimbulkan meliputi pencemaran udara, peningkatan kebisingan, timbulnya getaran, kecelakaan kerja, timbulan sampah padat dan limbah cair, kerusakan jalan dan gangguan kelancaran lalu lintas. Upaya pengelolaan lingkungan dilakukan untuk mengendalikan pemanfaatan sumber daya secara bijaksana mewujudkan manusia sebagai pembina lingkungan hidup melaksanakan pembangunan berwawasan lingkungan untuk kepentingan generasi sekarang dan generasi mendatang

\section{DAFTAR PUSTAKA}

Br Ginting, E. Y. (2017). Kajian Karakteristik Lingkungan Fisik Tambang Akibat Aktivitas Penambangan Pasir Di Desa Pasar Vi Kwala Mencirim Kecamatan Sei Bingai Kabupaten Langkat Tahun 2016 (Doctoral dissertation, UNIMED).

Gubernur DIY, 2007. Peraturan Daerah DIY Nomor 5 Tahun 2007 tentang Pengendalian Pencemaran Udara, Sekretaraiat Daerah, Yogyakarta.

Gubernur DIY, 2010. Peraturan Daerah DIY Nomor 2 Tahun 2010 tentang Rencana Tata Ruang Wilayah, Sekretaraiat Daerah, Yogyakarta.

Gubernur DIY, 2010. Peraturan Daerah DIY Nomor 2 Tahun 2010 tentang Rencana Tata Ruang Wilayah, Sekretaraiat Daerah, Yogyakarta. 
Gubernur DIY, 2002. Keputusan Gubernur Daerah Istimewa Yogyakarta Nomor 153 Tahun 2002 tentang Baku Mutu Udara Ambien Daerah di Propinsi Daerah Istimewa Yogyakarta, Sekretaraiat Daerah, Yogyakarta.

Gubernur DIY, 2003. Keputusan Gubernur Daerah Istimewa Yogyakarta Nomor 176 Tahun 2003 tentang Baku Mutu Tingkat Getaran, Kebisingan dan Kebauan di Propinsi Daerah Istimewa Yogyakarta, Sekretaraiat Daerah, Yogyakarta.

Herniti, D. Primanda Kiky W dan Ika Arsi A (2016). Kajian Dampak Sosial Ekonomi dan Lingkungan terhadap Penambangan Batu Akik di Kecamatan Samigaluh Kab Kulonprogo DIY. Jurnal Rekayasa Lingkungan, Hal.01-09, Vol 1 (2016).

Jolo, A. Y., \& Gautama, R. S. (2018). Pengelolaan dan Pemanfaatan Sumber Daya Mineral Berwawasan Lingkungan (Studi Kasus Kabupaten Halmahera Utara). Techno: Jurnal Penelitian, 7(01), 128142.

Kementerian Lingkungan Hidup, 2012. Peraturan Menteri Lingkungan Hidup Nomor 16 tahun 2012 tentang Pedomen Penyusunan Dokumen Lingkungan Hidup, Kementrian Lingkungan Hidup, Jakarta.

Kurniawan, A. R., \& Rauf, A. (2018, September). Rencana Reklamasi Pada Lahan Bekas Tambang Pasir Dan Batu Di Desa Nglumut, Kecamatan Srumbung, Kabupaten Magelang, Provinsi Jawa Tengah. In Prosiding Seminar Nasional Sains dan Teknologi Terapan (pp. 177-182).

Wibisono, B. (2013). Faktor-Faktor yang Berhubungan dengan Kejadian Kecelakaan Kerja Pada Pekerja Tambang Pasir Gali Di Desa Pegiringan Kabupaten Pemalang Tahun 2013. Universitas Dian Nuswantoro. Semarang. Skripsi.

Yudhistira, Y., Hidayat, W. K., \& Hadiyarto, A. (2011). Kajian dampak kerusakan lingkungan akibat kegiatan penambangan pasir di Desa Keningar daerah kawasan Gunung Merapi. Jurnal Ilmu Lingkungan, 9(2), 76-84. 